УДК 621.43 .068

\author{
A. P. POLIVYANCHUK ${ }^{1}$, D-r Techn. Sciences, Prof., O. I. KASLIN ${ }^{2}$, \\ O. O. SKURIDINA ${ }^{3}$ \\ ${ }^{1}$ O. M. Beketov National University of Urban Economy in Kharkiv \\ 17, Marshal Bazhanov Street, Kharkiv, 61002, Ukraine \\ e-mail: apmail@meta.ua \\ ${ }^{2}$ National Technical University "Kharkiv Polytechnic Institute" \\ 21, Kyrpychova str, Kharkiv, 61002, Ukraine \\ e-mail: dvs@kpi.kharkov.ua \\ ${ }^{3}$ Volodymer Dahl East Ukrainian National University \\ 59-a, pr. Central, Severodonetsk, 93400, Ukraine \\ e-mail: icd@snu.edu.ua
}

\title{
INCREASE OF HIGH-SPEED QUALITIES AND ECONOMIC EFFICIENCY OF USE SYSTEMS OF ECOLOGICAL DIAGNOSTICS DIESEL ENGINES - MICROTUNNELS
}

Purpose. Reducing the duration and cost of procedures for environmental diagnostics of diesel power plants by increasing the speed of measurements of normalizedPM index - average operating emissions of particulate matters with exhaust gases of diesel engines. Methods. Analysis and synthesis of information, mathematical modeling, experimental studies, calculation experiment. Results.In accordance with the requirements of the international standard ISO 8178, a method of accelerated measurement (MAM) of the PMindex is proposed, which is characterized by the maximum allowable sample filtration rate and the minimum allowable masses of particulate matter in the filters, the use of which can significantly improve the economic efficiency of applying microtunnels: with single- and multi-filter sampling methods - in 3,1 ...4,1 times and in 5,3 ... 7,1 times, respectively. Conclusions. Compared to the most common methods of control of particulate matter emissions that are realized in mini and microtunnels of Perkins, AVL, Mitsubishicompanies, they are characterized by higher speed and economic efficiency of use - indicators that are of great importance in testing high-power diesel engines -locomotive diesel, ships and others. It is substantiated that the use of MAM allows to shorten the duration and cost of environmental testing of mainline diesel engines - 2TE116 and shunting - TEM-2 locomotives: certification tests - by $9 \ldots 28 \%$, which is $0.2 \ldots 0.7 \mathrm{~h}$ and $0,8 \ldots 1,5$ thousand UAH; research tests $-43 \ldots 53 \%$, which is $1.7 \ldots 3.0 \mathrm{~h}$ and $4.0 \ldots 7.5$ thousand UAH. With the reduction of the actual emission levels of particulate matter with the exhaust gases of the diesel engine, the efficiency of the use of MAM increases.

Keywords: diesel, exhaust gases, particulate matter, ecological compatibility, microtunnel, accelerated measurement, efficiency

Полив'янчук А. П. ${ }^{1}$, Каслін О. I. ${ }^{2}$, Скурідіна О. О. ${ }^{3}$

${ }_{1}^{1}$ Харківський національний університет міського господарства імені О.М. Бекетова

${ }^{2}$ Національний технічний університет «Харківський політехнічний інститут»

${ }^{3}$ Східноукраӥнський наџіональний університет імені Володимира Даля

ПДВИЩЕННЯ ШВИДКОДІї ТА ЕКОНОМІЧНОЇ ЕФЕКТИВНОСТІ ВИКОРИСТАННЯ СИСТЕМ ЕКОЛОГІЧНОГО ДІАГНОСТУВАННЯ ДИЗЕЛІВ-МІКРОТУНЕЛІВ

Мета. Зменшення тривалості та вартості процедур екологічного діагностування дизельних силових установок різного призначення за рахунок підвищення швидкості вимірювань нормованого показника РМ - середньоексплуатаційного викиду твердих частинок з відпрацьованими газами дизеля. Методи. Аналіз та синтез інформації щодо нормативної бази, процедур випробувань, обладнання та рахункових методик для проведення екологічних випробувань дизелів; математичне моделювання та експериментальні дослідження параметрів ефективності процедури екологічного діагностування дизеля - тривалості, потребної кількості палива, вартості; розрахунковий експеримент з оцінки доцільності підвищення швидкості виміру показника РМ. Результати. Відповідно до вимог міжнародного стандарту ISO 8178 запропоновано спосіб прискореного виміру (СПВ) показника РМ, який характеризується максимальною допустимою швидкістю фільтрації проби - 100 см/м та мінімально допустимими масами навішувань твердих частинок на фільтрі: 0,25 мг - при однофільтровму методі відбору проб твердих частинок та 0,17 мг при багатофільтровму методі. Використання СПВ дозволяє суттєво покращити економічну ефективність застосування цих методів в мікротунелі - в 3,1 ... 4,1 рази та в 5,3 ... 7,1 разіз, відповідно. Висновки. Порівняно з найбільш поширеними сьогодні способами контролю викидів твердих частинок, які реалізуються в міні- та мікротунелях фірм Perkins, AVL, Mitsubishi, CПВ характеризується більш високими швидкодією та економічною ефективністю використання - показниками, які мають високу значимість при випробуваннях дизелів великої потужності - тепловозних, суднових та ін. Обгрунтовано, що використання СПВ дозволяє скоротити тривалість та вартість екологічних випробувань дизелів магістрального - 2 ТЕ116

(C) Polivyanchuk A. P., Kaslin O. I., Skuridina O. O., 2018

DOI: https://doi.org/10.26565/1992-4259-2018-18-11 
та маневрового - ТЕМ-2 тепловозів: сертифікаційних випробувань - на 9 ... 28\%, що становить 0,2 .. 0,7 год і $0,8 \ldots 1,5$ тис. грн.; дослідницьких випробувань - на $43 \ldots 53 \%$, що складає $1,7 \ldots 3,0$ год і 4,0 ... 7,5 тис. грн. Зі зменшенням фактичних рівнів викидів твердих частинок з вихлопними газами дизеля, ефективність використання СПВ зростає.

Ключові слова: дизель, відпрацьовані гази, тверді частинки, екологічність, мікротунель, прискорений вимір, ефективність

Поливянчук А. П. ${ }^{1}$, Каслин А. И. ${ }^{2}$, Скуридина Е. А. ${ }^{3}$

${ }^{1}$ Харьковский наииональный университет городского хозяйства имени А.Н. Бекетова

${ }^{2}$ Национальный технический университет «Харьковский политехнический институт»

${ }^{3}$ Восточноукраинский наииональный университет имени Владимира Даля

ПОВЫШЕНИЕ БЫСТРОДЕЙСТВИЯ И ЭКОНОМИЧЕСКОЙ ЭФФЕКТИВНОСТИ ИСПОЛЬЗОВАНИЯ СИСТЕМ ЭКОЛОГИЧЕСКОГО ДИАГНОСТИРОВАНИЯ ДИЗЕЛЕЙ МИКРОТУННЕЛЕЙ

Цель. Уменьшение продолжительности и стоимости процедур экологического диагностирования дизельных силовых установок за счет повышения скорости измерений нормированного показателя РМ среднеэксплуатационного выброса твердых частиц с отработавшими газами дизеля. Методы. Анализ и синтез информации, математическое моделирование, экспериментальные исследования, расчетный эксперимент. Результаты. Предложен способ ускоренного замера (СПВ) показателя РМ, который характеризуется максимально допустимой скоростью фильтрации пробы и минимально допустимыми массами навесок твердых частиц на фильтрах, использование которого позволяет существенно повысить экономическую эффективность использования микротуннелей. Выводы. Обосновано, что использование СПВ позволяет сократить продолжительность и стоимость сертификационных испытаний дизелей магистрального - 2ТЭ116 и маневрового - ТЭМ-2 тепловозов на $9 \ldots 28 \%$, что составляет $0,2 \ldots 0,7$ ч и $0,8 \ldots$ 1,5 тыс. грн.

Ключевые слова: дизель, отработанные газы, твердые частицы, экологичность, микротуннель, ускоренный замер, эффективность

\section{Introduction}

The process of ecologization of transport internal combustion engines is characterized by the phased introduction ofthe value of the average operational discharge of particulate matter (PM) with exhaust gases (EG) to the standardized indicators of the toxicity of diesel engines So, since 1993, this indicator has been measured during ecological tests of automobile diesel engines, since 1997 - diesel engines of agricultural machines, and since 2007 - ship and locomotive diesel engines. In the long run, the PM index will become the normalized value for other types of diesel engines: domestic, industrial, engines of special equipment, etc.

Since the beginning of the normalization of mass emissions of the PM, there appeared a problem of increasing the duration and cost of environmental tests of diesel engines due to increased time expenditures for determining PM. The essence of this problem is as follows. The normative basis for environmental tests of diesel engines is the international standard ISO 8178 [1-3]. This document provides determining the value of PM together with other indicators of toxicity of diesel EG - the average operational emissions of gaseous pollutants: nitrogen oxides, carbon monoxide and hydrocarbons designated as $\mathrm{GAS}_{\mathrm{x}}$. The $\mathrm{GAS}_{\mathrm{x}}$ and PM indices are determined during the test cycles, which consist of normalized engine operating modes [3]. At each mode sampling of pollutants for analysis is carried out. The technology for controlling PM emissions involves preliminary dilution of the engine EG with atmospheric air and then passing it through the PM sampling filters. In this case, the duration of the sampling is determined by the rate of its filtration and the hanging-on mass of PM that is collected on the filters. During testing one of two methods of sampling PM is possible: single-filter (SF), which involves the use of one filter over the whole test cycle or multi-filter (MF), which involves the use of one filter at each test mode.

The most commonly used way of controlling PM emissions, realized in microand minitunnels of Perkins, AVL [4, 5], Mitsubishi [6], is characterized by increased time expenditure on sampling PM, which substantially exceeds the sampling time for gaseous pollutants - 5- 7 minutes at each test mode. As a result, the procedure for determining the PM index is more time-consuming and more expensive than the GASx indicator control procedure: at the SF method $-1.2 \ldots 1.5$ times more; at the MF method - 1,9 ... 2,5 times. The indicated problem is of high relevance in testing high-power diesel engines, in particular - diesel locomotivediesels, marine engines, etc. 
To solve this problem and increase the economic efficiency of environmental tests of diesel engines, it is necessary to use more rapid methods of measurement of PM indicator.

\section{Object and methods of research}

Technical equipment, procedure for conducting environmental tests of diesel plants. According to the requirements of ISO 8178, environmental tests of diesels are carried out with the help of special equipment, which includes: loading device, system of selection and analysis of samples of gaseous pollutants (GP) and system of sampling and analysis of PM - microtunnel (Fig. 1).

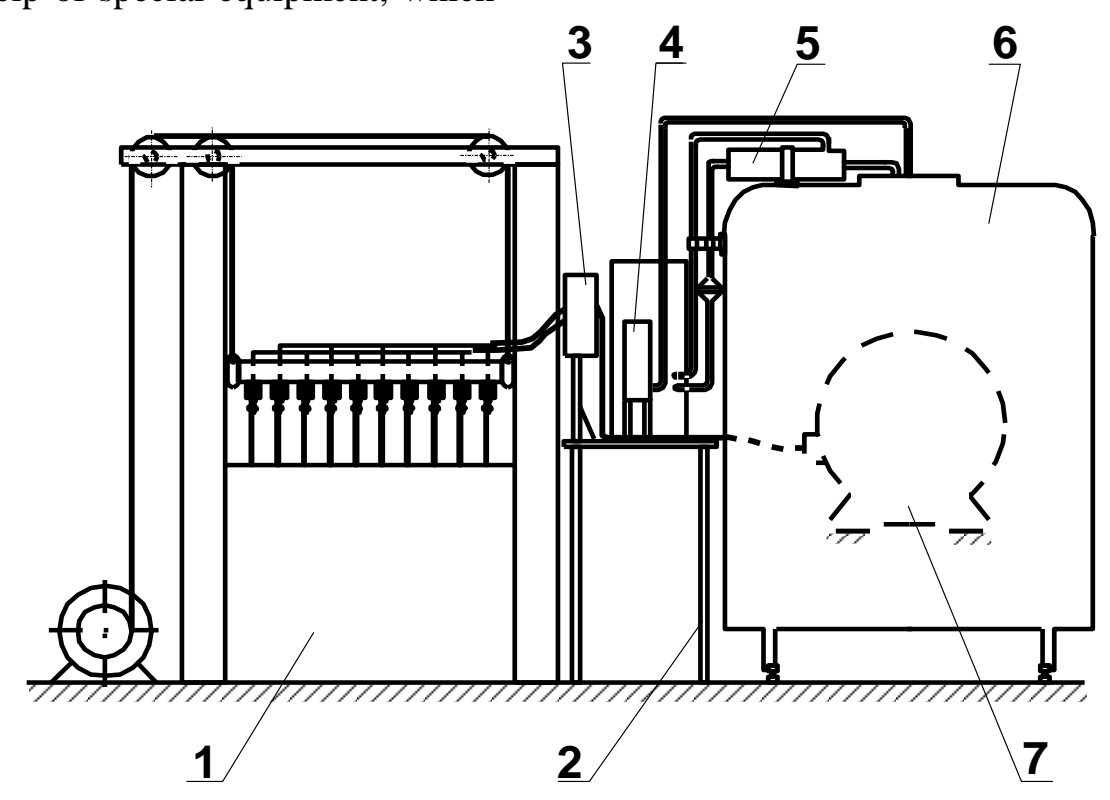

1 - loader (rheostat setup); 2 - a rack with devices; 3 - electric panel; 4 - system of selection and analysis of GP samples; 5 - PM emission control system (microtunnel); 6 - locomotive; 7 - diesel installation.

Fig. 1 - Equipment for ecological diagnostics of locomotive diesel engines

The loading device is used to control the diesel load in the entire range of operating modes of its operation. The system of selection and analysis ofGP samples is intended for measurement of concentrations of gaseous substances contained in diesel EG. This system includes: devices for the selection and transportation of gas samples and gas analyzers.

Devices for the selection and transporttation of gas samples are used to select the amount of EG samples necessary for the analysis and to bring it to gas analyzers. These devices must ensure the immutability of the sample when it is transported from the place of selection to the site of analysis. The control and registration of concentrations of GP in selected samples are carried out by means of gas analyzers. To measure the $\mathrm{GAS}_{\mathrm{x}}$ normalized parameters, the system for the selection and analysis of GP samples must contain appropriate gas analyzers. In samples selected, the content of other substances, such as: carbon dioxide, oxygen, sulfur dioxide, etc. can also be monitored. The PM sampling and analysis system (microtunnel) is used to measure the concentration of PM contained in diesel EG.

The procedure for ecological diagnostics of a diesel engine is a cycle, which consists of normalized modes of its operation in accordance with the requirements of ISO 8178 [3]. Taking into account the real conditions of operation of a diesel engine is carried out by using weight factors of the test modes WF, which are equal to the relative durations of diesel operation atthese modes during its service (Table 1).

The control ofpollutants emissions from diesel EG is carried out as follows. The test starts from the pre-warming stage of the diesel engine in anidlingconditions. This stage is considered to be completed if the regulated values of temperatures and pressures of water and lubricationoil in the systems of cooling and lubrication of a diesel engine have been achieved. 
Characteristics of the test cycle ISO 8178-F for ecological diagnostics of diesel locomotives

\begin{tabular}{|c|c|c|}
\hline $\begin{array}{c}\text { Cycle } \\
\text { mode }\end{array}$ & $\begin{array}{c}\text { Diesel power (in\% of } \\
\text { nominal value) }\end{array}$ & $\begin{array}{c}\text { Weight } \\
\text { factor WF }\end{array}$ \\
\hline 1 & 100 & 0,25 \\
\hline 2 & 35 & 0,15 \\
\hline 3 & Idling conditions & 0,60 \\
\hline
\end{tabular}

After this the test cycle begins - the successive work of the diesel engine on each standardized test mode, which consists of two stages: temperature stabilization of the diesel engine and sampling pollutants. During the stage of temperature stabilization of the diesel, stabilization of water temperature, lubricationoil and EG, as well as water and oil pressure in the systems of cooling and lubrication of diesel, is achieved. During the samplingpollutants phase a parallel sampling is performed for the analysis of GP and PM contained in the diesel EG. In this case, the sampling of PM can be doneby two methods: SF and MF. At the SF method, sampling PM is carried out by using one filter throughout the test cycle, and at the MF method - by using one filter at each test mode. SF method allows to determine only the indicator of average operational PM emissions and is used in the course of certification tests of diesel engines; the MF method allows to determine the mass PM emissions at the normalized operating modes of the engine and the index of average operational $\mathrm{PM}$ emissions and is used in conducting research tepollutants sts of diesel engines.

During the samplingpollutants phase the requirements for limiting the sampling time must be fulfilled. According to ISO 8178 the minimum durationof the GP sampling procedure is 5 minutes, it requires at least 3 measurements of GP concentrations per a test mode with $1 \mathrm{~min}$ intervals. The minimum allowable duration of the PM sampling procedure is determined indirectly and depends on such parameters of the PM emission control system as the velocity of the filtration of the diluted EG sample and the mass of the PM accumulated on the filters. The minimum permissible duration of the sampling period for pollutants in each mode is defined as the highest of the minimum allowable lengths of sampling procedures for GP and PM.

After performing the test cycle, the results of the tests determine the $\mathrm{GAS}_{\mathrm{x}}$ and RT.

Analysis of the possibility of increasing the rate of measurement of PM indicator. ISO 8178 has the following limitations of parameters that affect the velocity of PM mass emissions: the filtration rate of a diluted EG-vf sample must be in the range of $35 \ldots 100 \mathrm{~cm} / \mathrm{s}$; The hangingon mass of the PM collected in the filters must not be less than the minimum acceptable value: at the SF method, $\mathrm{M}_{\mathrm{f}(\min )}=0.25 \mathrm{mg}$, at the MF method, $\mathrm{M}_{\mathrm{fi}(\mathrm{min})}=0.14 \mathrm{mg}$ (using filters with70 $\mathrm{mm}$ in diameters) [1].

The most common methods for controlling PM emissions are characterized by sample filtration velocities - vf $=60 \ldots 80 \mathrm{~cm} / \mathrm{s}$ and hanging-on masses of PM at the SF and MF methods of sampling $-\mathrm{M}_{\mathrm{f}}=\mathrm{M}_{\mathrm{fi}}=1.3 \mathrm{mg}$ (Fig. 2).

As can be seen from Fig. 2, the normative requirements allow the implementation of the method ofaccelerated PM measurement (MAM), which is characterized by the maximum permissible rate of filtration of the sample $-\mathrm{v}_{\mathrm{f}}$ (max) $=100 \mathrm{~cm} / \mathrm{s}$ and the minimumpermissiblehanging-on mass of PM $\mathrm{M}_{\mathrm{f}(\min )}=0.25 \mathrm{mg}$ and $\mathrm{M}_{\mathrm{fi}(\min )}=0.14 \mathrm{mg}$. Application of this method allows to reduce the time expenditure on PM sampling: at the SF method - 3,1 ... 4,1 times less; at the MF method - $5.3 \ldots 7.1$ times and, consequently, reduce the cost of diesel environmental tests procedure.

It should be noted that the reduction of the hanging-on mass of PM to the minimum allowable value leads to a certain decrease in the accuracy of measurements of PM index. However, as shown by studies presented in papers [7-9], the resulting error of measurements of the PM index while implementating MAM does not exceed the permissible value $- \pm 8.5 \%$ [2], and, therefore, this method can be applied in practice.

The method of evaluating the expediency of using the method of accelerated PMmeasurement involves a comparative analysis of the effectiveness of two ways of measuring the PM index (see Figure 2) oneof the fastest contemporarymethods - method 1 and MAM - method 2. As the criteria of efficiency of these methods, the following is used: 


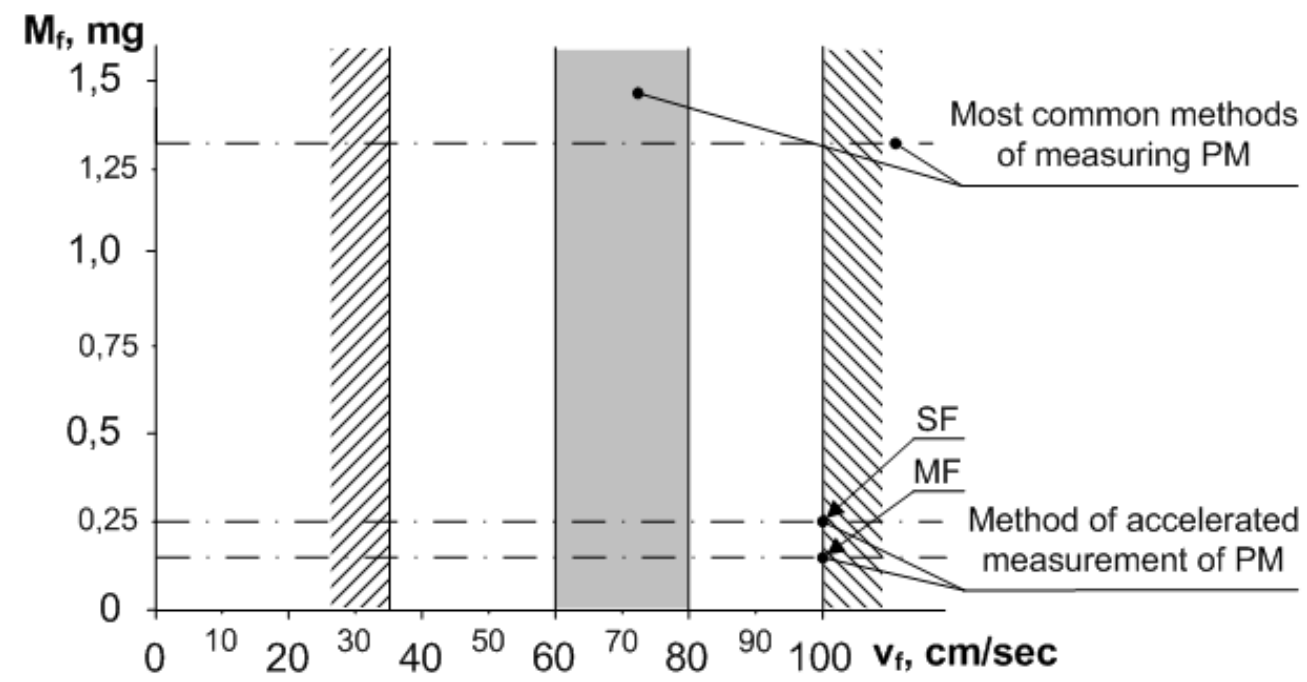

Fig. 2 - Values of factors that determine the rate of measurements of the PM indicator

A) absolute values: duration of tests $\tau^{\text {test }}$, fuel consumption while testing $-\mathbf{M}_{\text {fuel }}^{\text {test }}$ and cost of tests $-\mathrm{C}^{\text {test }}$, which are determined by the expressions:

$$
\tau^{\text {test }}=\tau^{\text {hast }}+\sum_{i=1}^{n}\left(\tau_{i}^{\text {st }}+\max \left\{\tau_{i}^{\operatorname{san}(G A S A)} ; \tau_{i}^{\operatorname{san}(\text { PMD }}\right\}\right) \text {, }
$$

where $\tau^{\text {heat }}-$ duration of pre-warming stage of a diesel engine, $\mathrm{h}$;

$\mathrm{n}$ - number of test cycle modes (for the ISO 8178-F series cycle $n=3$ );

$\tau_{i}^{\text {st }}$ - time expenditure for temperature stabilization of diesel, $\mathrm{h}$;

$$
\tau_{\mathrm{i}}^{\mathrm{sam}(\mathrm{GASx})} \text { and } \tau_{\mathrm{i}}^{\mathrm{sam}(\mathrm{Pam}}-\text { duration of }
$$

gaseous pollutants and PM sampling, respectively, year;

$$
\begin{aligned}
& M_{\text {flel }}^{\text {test }}=G_{\text {fluel }}^{\text {heat }} \tau^{\text {heat }}+ \\
& +\sum_{i=1}^{n}\left(G_{\text {fleil }} \times\left(\tau_{i}^{s t}+\max \left\{\tau_{i}^{\operatorname{san}(G A S X)} ; \tau_{i}^{\operatorname{sam}(P M)}\right\}\right)\right)
\end{aligned}
$$

where $G_{\text {fuel }}^{\text {heat }}$ - fuel consumption at the stage of pre-heating of the diesel engine, $\mathrm{kg} / \mathrm{h}$;

$$
\mathrm{G}_{\text {fueli }} \text { - fuel consumption at i-mode test, }
$$
$\mathrm{kg} / \mathrm{h}$;

$\mathrm{C}^{\text {test }}=\mathrm{M}_{\text {fuel }}^{\text {test }} \times \mathrm{c}_{\text {fuel }}+\mathrm{k}_{\text {oil }} \times \mathrm{M}_{\text {fuel }}^{\text {test }} \times \mathrm{c}_{\text {oil }}+\tau^{\text {test }} \times \mathrm{c}_{\text {test }}$

where $c_{\text {fuel }}, c_{\text {oil }}-$ specific values of the cost of fuel and lubricationoil, respectively, in UAH / $\mathrm{kg}$;

$c_{\text {test }}-$ cost of one hour of personnel work, $\mathrm{UAH} / \mathrm{h}$;

$\mathrm{k}_{\mathrm{oil}}$ - coefficient equal to the ratio of the mass of the lubricationoil to the mass of fuel consumed during the tests;

B) the relative values: the duration of the tests $-\overline{\tau^{\text {test }}}$, the fuel consumption for their carrying out $\overline{\mathrm{M}_{\text {fuel }}^{\text {test }}}$, and the cost of the tests $\overline{\mathrm{C}^{\text {test }}}$, which are defined as the ratio of $\tau^{\text {test }}$, $\mathrm{M}_{\text {fuel }}^{\text {test }} \mathrm{i}^{\mathrm{test}}$ corresponding to the procedure for determining $\mathrm{PM}$ index to the corresponding quantities conformto the procedure of determining $\mathrm{GAS}_{\mathrm{x}}$ indicators.

\section{Results and discussion}

Investigations of theexpediency of using MAM were conducted on the basis of the results of environmental tests of the mainline 2TE116 and shunting - TEM-2 diesel locomotives equipped with diesel engines $1 \mathrm{~A}$ 5D49 and PD1M, respectively [10, 11]. As a sampler device, a universal system for ecological diagnostics of diesels was considered - the microtunnel MKT-2 $[12,13]$ with the compensatory sampling EG method [14] and the temperature control of thesample preparation for analysis [15]. In the course of the researchtherehas been estimated the influenceof the gradual reduction of the emission norms of PM emissions from diesel EG on the efficiency of the MAM factor as a result of environmental standards improvement.. This factor was taken into account by using a relative magnitude equal to the ratio of current and future levels of PM emissions.

The results of the research prove the cost-effectiveness of using MAM at railway 
transport, as well as in other industries where diesel plantswhich are characterized by significant fuel consumptions are used (Figures 3, 4).

Thus, during the environmental tests of locomotive diesel engines, the duration, fuel
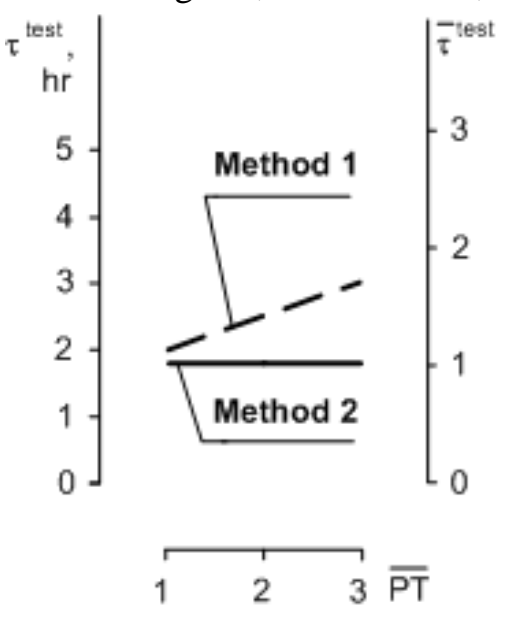

consumption and cost of tests are reduced: at the SF method - by $9 \ldots 28 \%$, which is pera test $0,2 \ldots 0,7$ hours, $25 \ldots 45 \mathrm{~kg}$ and $0,8 \ldots 1,5$ thousand UAH; atthe MF method - by 43 ...
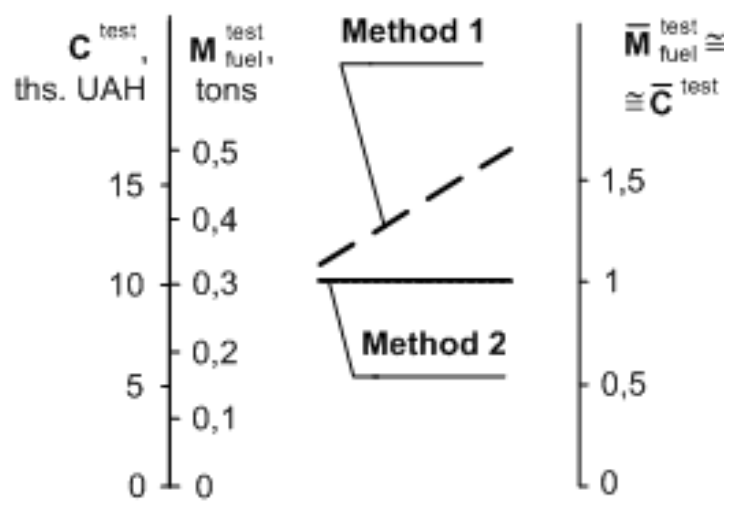

a)
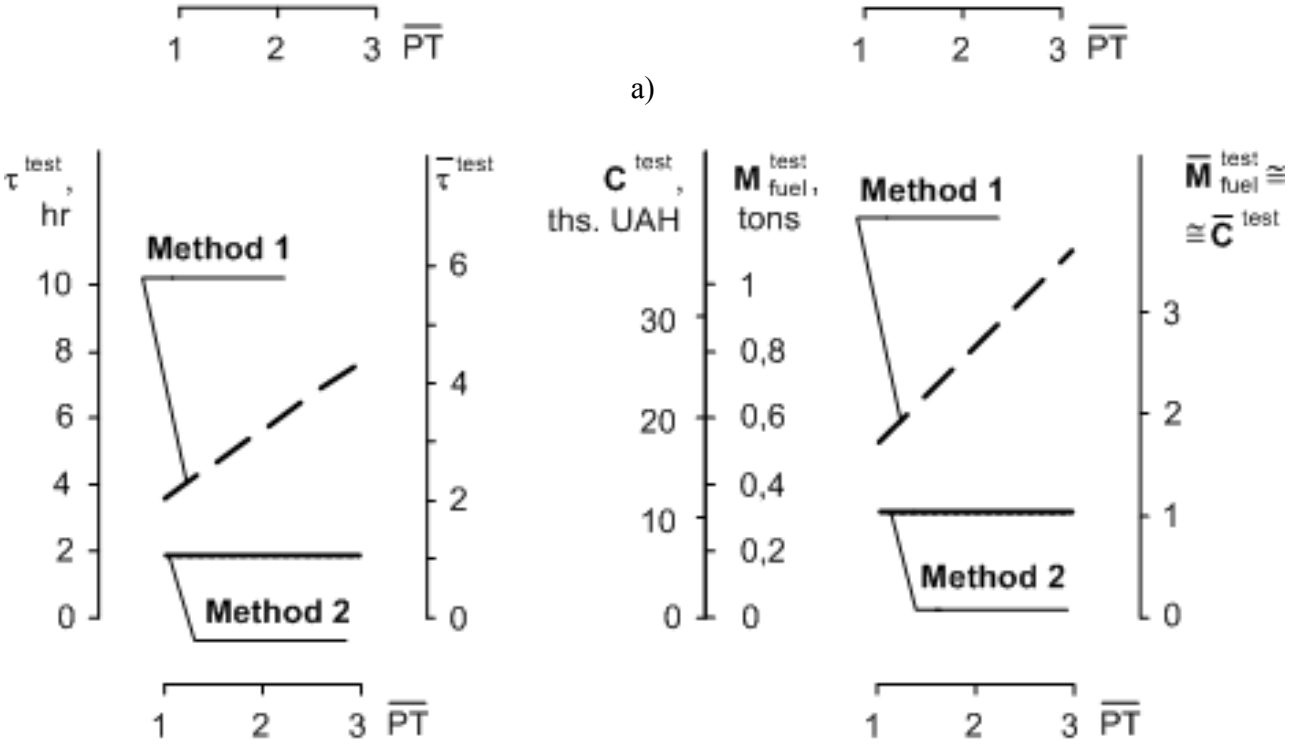

б)

Fig. 3 - Results of the comparative analysis of the efficiency of methods 1 and 2 while testing the main locomotive 2TE116 using SF (a) and MF (b) PM selecting methods

$53 \%$, which is pera test $1,7 \ldots 3,0$ hours, $120 \ldots$ $225 \mathrm{~kg}$ and 4,0 ... 7,5 thousand UAH. With the decrease of PM emission levels , the efficiency of the MAM increases: with PM increase for each unit, the values $\tau^{\text {test }}, \mathbf{M}_{\text {fuel }}^{\text {test }}$ and $\mathbf{C}^{\text {test }}$ decrease further: at the SF method - by $0,3 \ldots$ $0,7 \mathrm{~h}, 45 \ldots 55 \mathrm{~kg}$ and 1,5. .1,8 thousand $\mathrm{UAH}$; at the MF method - by 1,7 ... 3,0 years, $115 \ldots$ $235 \mathrm{~kg}$ and 3,8 ... 7,8 thousand UAH.

\section{Conclusions}

1. With the beginning of the normalization of the average specific emission of particulates (PM) with exhaust gases (EG) of diesel plants due to the lack of high speed of PM index measurement, the duration and cost of the procedure of ecological tests of diesel engines significantly increase: with the use of a single-filter (SF) PM sampling method - in 1,2 ... 1,5 times, multiphase (MF) method - in 1,9 ... 2,5 times.

2. In accordance with the requirements of the international standard ISO 8178 a method of accelerated PM index measurement - MAM is proposed.It is characterized by the maximum 

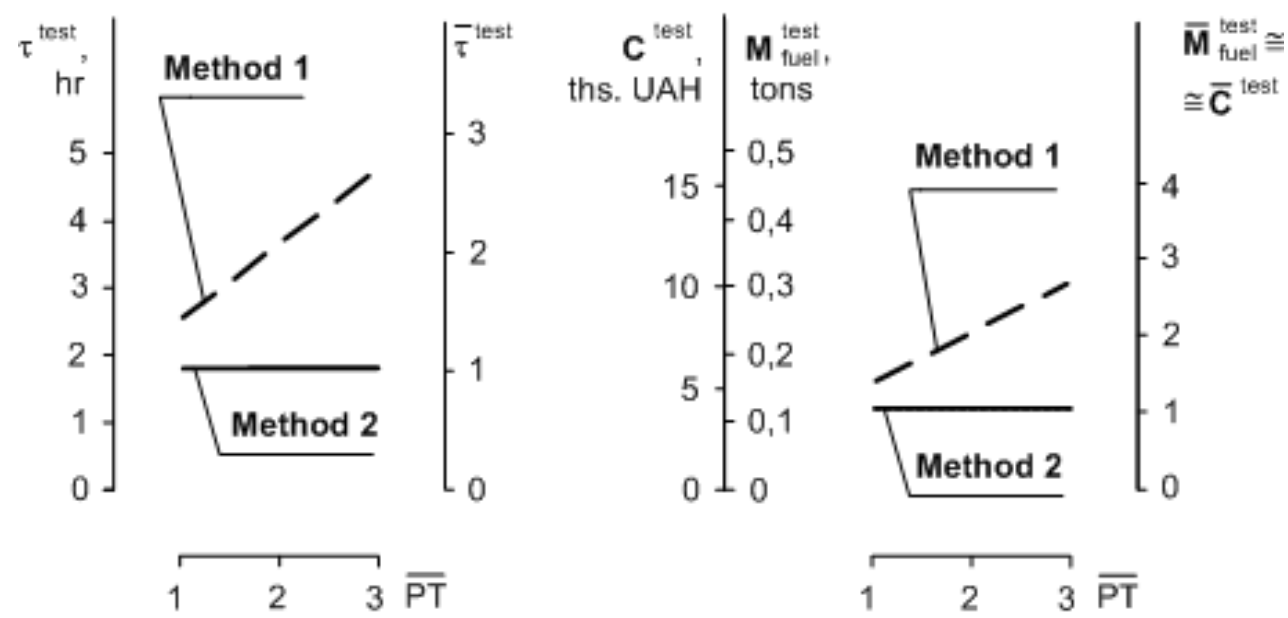

a)
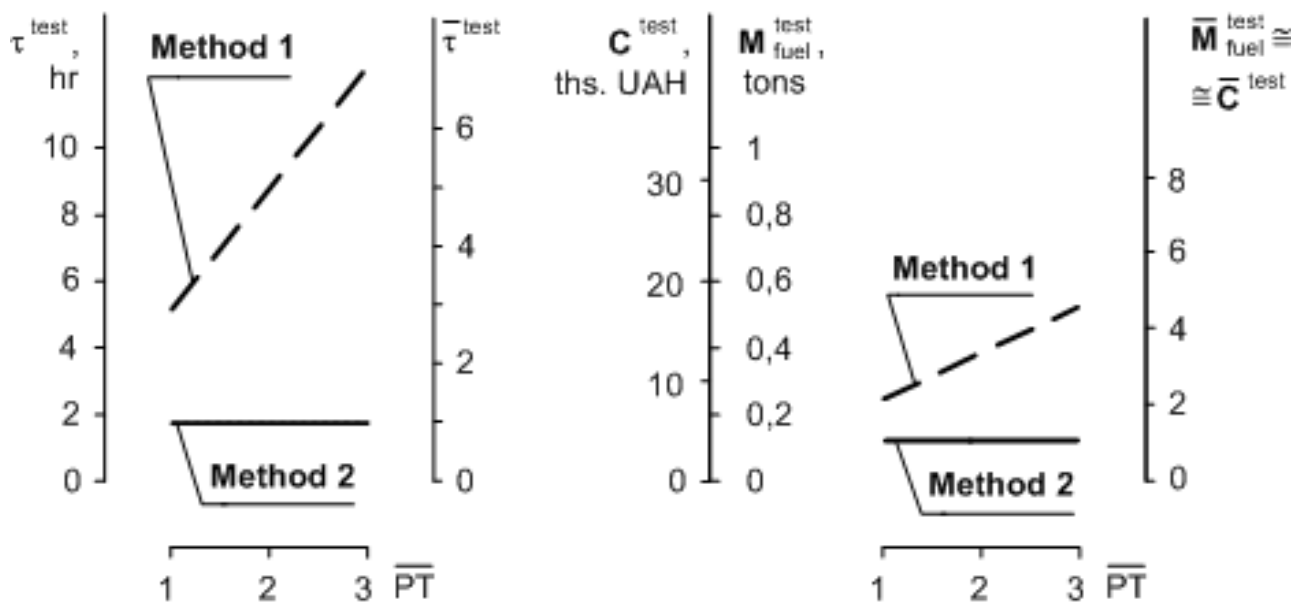

б)

Fig. 4 - Results of the comparative analysis of the effeciency of methods 1 and 2 while testingthe shunting diesel locomotive TEM-2 using SF (a) and MF (b) PM selecting methods

permissible rate of filtering of the PMsample $100 \mathrm{~cm} / \mathrm{s}$ and the minimum allowable hanging-on masses of PM collected on the filters $0,25 \mathrm{mg}$ and $0.14 \mathrm{mg}$ by using $\mathrm{SF}$ and $\mathrm{MF}$ methods for PM selection, respectively. The use of MAM can significantly increase the speed of measuring PM index: at the SF method - in 3.1 ... 4.1 times, at the MF method - in 5.3 ... 7.1 times.

3. Compared with the most widespread methods of monitoring PM emissions, which are realized in mini-microtunnels of Perkins, AVL, Mitsubishi, MAM is characterized by higher speed and economic efficiency of use - indicators that are of high importance in testing diesel engines of high power - locomotive diesel, ship and etc. The use of MAM can reduce the duration, fuel consumption and cost of testing locomotive diesel engines: at the SF method - by $9 \ldots 28 \%$, which is per a test 0,2 ... 0,7 hours, $25 \ldots 45 \mathrm{~kg}$ and $0,8 \ldots 1,5$ thousand UAH; at the MF method - by $43 \ldots$ $53 \%$, which is per a test $1,7 \ldots 3,0$ hours, 120 ... $225 \mathrm{~kg}$ and 4,0 ... 7,5 thousand UAH. With the reduction of the actual levels of PM emissions from the diesel EG, the effectiveness of the use of MAM increases.

\section{Literature}

1. ISO 8178-1: 2017. Reciprocating internal combustion engines - Exhaust emission measurement - Part 1: Test - bed measurement of gaseous and particulate exhaust emissions, 2017. $150 \mathrm{p}$.

2. ISO 8178-2: 2008. Reciprocating internal combustion engines - Exhaust emission measurement - Part 2: Test - Measurement of gaseous and particulate exhaust emissions at site, 2008. $19 \mathrm{p}$.

3. ISO 8178-4: 2017. Reciprocating internal combustion engines - Exhaust emission measurement - Part4: Test cycles for different engine applications, 2017. $237 \mathrm{p}$. 
4. Smart Sampler PC SPC 472. PC program for SPC 472 control. AVL, List GmbH Graz, 1993. 76 p.

5. Lianga Z., Tiana J., Rezaeia S., Zhanga Y. Investigation of SVOC nanoparticle emission from light duty diesel engine using $\mathrm{GC} \times \mathrm{GC}-\mathrm{ToF}-\mathrm{MS}$. School of Mechanical Engineering, University of Birmingham. 2015. $31 \mathrm{p}$.

6. Hirakouchi N., Fukano I., Shoji T. Measurement of Diesel Exhaust Emissions with MiniDilution Tunnel. SAE Technical Paper Series. 1989. № 890181. 11p.

7. Поливянчук А.П. Повышение точности гравиметрического метода измерений удельного выброса твердых частиц с отработавшими газами дизеля. Двигатели внутреннего сгорания. 2010. №2. С. 110-113.

8. Поливянчук А.П. Оценка неопределенности результатов измерений выбросов твердых частиц в ходе экологических испытаний дизелів. Вісник Східноукраїнського національного університету ім. В. Даля. 2012. №5 (176), Ч.2. С. 121-128.

9. Полив'янчук А. П., Харитонова Т.С., Чумак О.О. Дослідження ефективності використання вимірювального комплексу з мікротунелем МКТ-2 при проведенні екологічного діагностування тепловозів. $\mathrm{Bi}$ сник Східноукраїнського національного університету ім. В.Даля. 2007. № 8(114). С. 119-124.

10. Полив'янчук А.П., Львов С.О., Зубов С.В. Оцінка індивідуального внеску основних забруднюючих речовин у сумарну токсичність відпрацьованих газів тепловозів. Международный информационный научно-технический журнал Локомотивинформ. 2010. №5. С. 61-62.

11. Полив'янчук А.П. Математичне моделювання процесів тепловіддачі в системах екологічного діагностування тепловозів - тунелях. Вісник Харківського наџіонального університету ім. В.Н. Каразіна. Серія «Екологія». 2017. Випуск №16. С. 96-106.

12. Polivyanchuk A.P. The concept of creating universal systems for the environmental certification of transport diesels based on mini- and microtunnels. Вісник Харківського начіонального університету ім. В.Н. Каразіна. Серія «Екологія». 2017. Випуск №17. С. 130-137.

13. Полив'янчук А.П., Каслін О.І., Смирний М.Ф., Строков О.П., Скурідіна О.О. Створення на базі мікротунелю універсальної системи динамічного контролю викидів дизельних твердих частинок. Людина та довкілля. Проблеми неоекології. 2017. № 3-4 (28). С. 141-153.

14. Полив'янчук А., Каслін О., Смирний М., Строков О., Скурідіна О. Впровадження компенсаційного методу контролю проби в універсальних системах екологічного діагностування дизелів - мікротунелях. Вісник ХНУ ім. В.Н. Каразіна. Серія "Екологія". 2017. №17. С. 80-88.

15. Поливянчук А., Скуридина Е., Каслин А. Повышение эффективности систем экологического диагностирования дизельных силовых установок - туннелей. Людина та довкілля. Проблеми неоекології. 2016. №3-4(26). C. 132-140.

\section{References}

1. ISO 8178-1: 2017. (2017). Reciprocating internal combustion engines - Exhaust emission measurement Part 1: Test - bed measurement of gaseous and particulate exhaust emissions, 150.

2. ISO 8178-2: 2008. (2008). Reciprocating internal combustion engines - Exhaust emission measurement Part 2: Test - Measurement of gaseous and particulate exhaust emissions at site, 19.

3. ISO 8178-4: 2017. (2017). Reciprocating internal combustion engines - Exhaust emission measurement Part4: Test cycles for different engine applications, 237.

4. Smart Sampler PC SPC 472. (1993). PC program for SPC 472 control. AVL, List GmbH Graz, 76.

5. Lianga, Z., Tiana, J., Rezaeia, S., Zhanga, Y. (2015). Investigation of SVOC nanoparticle emission from light duty diesel engine using GC $\times$ GC-ToF-MS. School of Mechanical Engineering. University of Birmingham, 31. [in English].

6. Hirakouchi N., Fukano I., Shoji T. (1989). Measurement of Diesel Exhaust Emissions with MiniDilution Tunnel. SAE Technical Paper Series, 890181. 11. [in English].

7. Polivyanchuk, A. (2010). Povyshenie tochnosti gravimetricheskogo metoda izmerenij udelnogo vybrosa tverdyh chastic s otrabotavshimi gazami dizelya. [Improving the accuracy of the gravimetric method for measuring the specific emission of solid particles with exhaust gases of a diesel engine]. Internal combustion engines, 2, 110-113. [in Russian].

8. Polivyanchuk, A. (2012). Ocenka neopredelennosti rezultatov izmerenij vybrosov tverdyh chastic v hode ekologicheskih ispytanij dizelej. [Estimation of the uncertainty of the results of measurements of particulate emissions during the environmental tests of diesel engines]. Visnyk of the East Ukrainian National University memory V. Dal, 5(176), P.2. 121-128. [in Russian].

9. Polivyanchuk, A., Haritonova, T., Chumak, O. (2007). Doslidzhennya efektivnosti vikoristannya vimiryuvalnogo kompleksu z mikrotunelem MKT-2 pri provedenni ekologichnogo diagnostuvannya teplovoziv. [Investigation of the effectiveness of using a measuring complex with microtunnel MKT-2 during the ecological diagnostics of diesel locomotives]. Visnyk of the East Ukrainian National University memory V. Dal, 8(114). 119-124. [in Ukrainian]. 
10. Polivyanchuk, A., Lvov, S., Zubov, S. (2010). Ocinka individualnogo vnesku osnovnih zabrudnyuyuchih rechovin u sumarnu toksichnist vidpracovanih gaziv teplovoziv. [Assessment of the individual contribution of the main pollutants to the total toxicity of the exhaust gases of diesel locomotives]. International information scientific and technical journal Lokomotivinform, 5, 61-62. [in Ukrainian].

11. Polivyanchuk, A. (2017). Matematichne modelyuvannya procesiv teploviddachi v sistemah ekologichnogo diagnostuvannya teplovoziv - tunelyah. [Mathematical modeling of heat transfer processes in ecological diagnostic systems of locomotives - tunnels]. Visnyk of V. N.Karazin. Kharkiv National University of Series «Ecology», 16, 96-106. [in Ukrainian].

12. Polivyanchuk, A. (2017) The concept of creating universal systems for the environmental certification of transport diesels based on mini- and microtunnels. Visnyk of V. N.Karazin. Kharkiv National University of Series «Ecology», 17, 130-137. [in English].

13. Polivyanchuk A., Kaslin O., Smirny M., Strokov O., Skuridina O. (2017). Stvorennia na bazi mikrotuneliu universalnoi systemy dynamichnoho kontroliu vykydiv dyzelnykh tverdykh chastynok. [Creation of the universal system of dynamic control of emissions of diesel solid particles on the basis if microtunnel]. Man and the environment. Issues of neoecology, 3-4(28), 139-151. [in Ukrainian].

14. Polivyanchuk A., Kaslin O., Smirny M., Strokov O., Skuridina O. (2017). Vprovadzhennia kompensatsiinoho metodu kontroliu proby $\mathrm{v}$ universalnykh systemakh ekolohichnoho diahnostuvannia dyzeliv - mikrotuneliakh. [Introduction of the compensatory method of gas sample control in universal systems of ecological diagnostics of diesel engines - microtunnels]. Visnyk of V. N.Karazin. Kharkiv National University of Series «Ecology», 17, 80-88. [in Ukrainian].

15. Polivyanchuk, A., Skurydyna, A. Kaslin, I. (2016). Povyshenie ehffektivnosti sistem ehkologicheskogo diagnostirovaniya dizel'nih silovih ustanovok - tunnelej. [Increasing the effectiveness of environmental diagnostic systems for diesel power plants - tunnels]. Man and the environment. Issues of neoecology, 34(26), 132-140. [in Russian].

Надійшла до редколегії 25.05.2018 